\title{
Environmental implications of N-Shaped Environmental Kuznets Curve for E7 Countries
}

\section{Bright Akwasi Gyamfi}

Faculty of Economics and Administrative Sciences,

Cyprus International University

Nicosia, North Cyprus, Via Mersin 10, Turkey

Email: brightgyamfi1987@gmail.com

\section{Festus Fatai ADEDOYIN}

Department of Accounting, Economics and Finance, Bournemouth University, United Kingdom Email: fadedoyin@bournemouth.ac.uk

Murad A. Bein

Faculty of Economics and Administrative Sciences

Cyprus International University

Nicosia, North Cyprus

Via Mersin 10, Turkey

Email: muradabdurahmanb@gmail.com

\section{Festus Victor Bekun ${ }^{1}$}

Faculty of Economics Administrative and Social sciences, Istanbul Gelisim University, Istanbul, Turkey

\&

Department of Accounting, Analysis and Audit,

School of Economics and Management

South Ural State University, 76, Lenin Aven., Chelyabinsk, Russia 454080.

E-mail: fbekun@gelisim.edu.tr

\footnotetext{
${ }^{1}$ Corresponding author: Festus Victor Bekun; Email: fbekun@gelisim.edu.tr
} 


\section{Abstract}

39 The Environmental Kuznets Curve (EKC) hypothesis is of great importance to understanding the 40 relationship between economic activity and environmental degradation. Given the current wave of

41 climate change and environmental crisis traced to rising environmental pollution from economic

42 activities it has become important to investigate the impact of economic expansion on the

43 environment especially in the Emerging-7 countries that are responsible for a large amount of global

44 economic activity. This study investigates the N-shaped EKC for the E-7 countries using data 45 spanning the period 1995 to 2018. The study employs the use of PMG-ARDL estimator and

46 heterogeneous causality tests to establish the long run and short-run and direction of causality

47 respectively regarding the variables of interest. According to study empirical results, the long-run

48 results fail to confirm the presence of an $\mathrm{N}$-shaped $\mathrm{EKC}$ in the emerging 7 countries but rather

49 confirms the existence of an inverted U-shaped EKC in the study countries. While renewable energy

50 and non-renewable energy have a positive and significant relationship with $\mathrm{CO}_{2}$ emissions. Short-run

51 results show that there is no significant relationship between economic expansion, renewable energy,

52 non-renewable energy and $\mathrm{CO}_{2}$ emissions. Causality tests showed a bi-directional causality between

53 GDP and GDP-squared, and a uni-directional causality from $\mathrm{CO}_{2}$ emissions to GDP-cubed, non-

54 renewable energy and $\mathrm{CO}_{2}$ emissions, renewable energy and $\mathrm{CO}_{2}$ emissions. The study suggests

55 increased use of renewable energy to mitigate pollutant emissions in the E-7 countries.

56 Keywords: Environmental Kuznets Curve; Economic Growth; Renewable Energy; Non-renewable 57 Energy; $\mathrm{CO}_{2}$ emissions 


\section{Introduction}

Pollution is one of the main critical issues in the globe currently (IPCC, 2014). Following the

65 ratification of Paris Summit meeting in 2015, popularly referred to as the 21st Conference of the

66 Parties (COP21), a range of targets was set to hold atmospheric warming levels comfortably outside

$67 \quad 2^{\circ} \mathrm{C}$ (United Nations, 2017). In an attempt to overcome the global warming problems against

68 sustainable and social development and to meet the ambitions of COP21, it is essential to take into

69 account the environmental effects of global development. Climate pollution could have catastrophic

70 effects for society, such as natural hazards, flooding, water shortages, habitat destruction and

71 negatively impacted global development (IPCC, 2014). Around the very moment, mankind action was

72 known as the primary cause of environmental warming (Steffen et al. 2011).

Within the ecological economics research, the correlation regarding ecological destruction and

74 sustainable development is fine established as the Kuznets environmental curve (EKC). The EKC

75 indicates that air pollution is gradually on the increase in income per capita. Furthermore, through

76 global stability, there is a rise in request for waste management, contributing to a deteriorating

77 degradation of the ecosystem (Hussen, 2005). When the U-shaped EKC is reversed, climate changes

78 will inevitably arise as populations develop. Consequentially, despite major variations, society would

79 return to life as normal and yet maintain ecological protection (Stern, 2004). Moreover, analyses have

80 shown that the connection can sometimes be $\mathrm{N}$-shaped as documented in a study of see (Bhattarai et

81 al. 2009), indicating that ecological pollution would begin to increase immediately above a reasonable

82 point of earnings.

The concept of the EKC phenomenon is focused on the relationship involving fiscal

84 expansion and environmental devastation and how the trajectory of growth in the economy will

85 adversely affect the nature of the ecosystem. As shown by Grossman (1995), this influence will occur 86 across three sources, namely the effect of scale, the effect of structure and the effect of a technique. 
87 When economic expansion sets the tempo, it has a scale impact on the climate. To promote economic

88 development, the market for natural resource extraction is growing and, as a result, the internal and

89 external use of valuable resources is converted into the manufacturing cycle. If the manufacturing

90 cycle begins, a considerable amount of toxic chemicals is produced and this by-product of

91 manufacturing and technological development poses a severe challenge to the sustainability of the

92 ecosystem. To enhance growth in the economy, governments neglect the harm to ecological health

93 and, as a result, climate harm beginnings to increase as economic development increases. This

94 phenomenon is evident, particularly when the market is primarily based on dominant (farming) and

95 supplementary (production and industrial) fields. Now since wages are increasing, the economic

96 system of the country continues to experience transition, and so the makeup of the market begins to

97 change. This is where sustainable expansion has a compositional influence on climate stewardship,

98 and this is where the effects of socioeconomic progress on climate sustainability start to be beneficial.

99 Throughout this process, the supplementary market is starting to grow and the industry is moving 100 towards sustainable technologies. This manufacturing transition is mirrored in the trend of 101 urbanization, and the desire for a healthier society is beginning to increase. It is the moment when 102 companies tend to adopt sustainable efficiency-enhancing technology. This advancement on the road 103 of technological transformation is how social development has a scientific impact on climate 104 sustainability. Throughout this cycle, the tertiary field is starting to develop, and the economic 105 environment is progressively starting to become information-intensive rather than wealth-intensive.

106 This is the moment when the government is beginning to spend more in innovation and production107 based operations, and the outdated and polluting technology used in the secondary field is beginning 108 to be replaced. Currently, if this complex trend is visually depicted, it can be shown that habitat 109 destruction proceeds on a bell-shaped or inverted U-shaped curves when mapped toward sustainable 
110 development. This whole theory is pointed to as the EKC theory (Shahbaz \& Sinha 2019; Agboola \&

111 Bekun, 2019).

112.

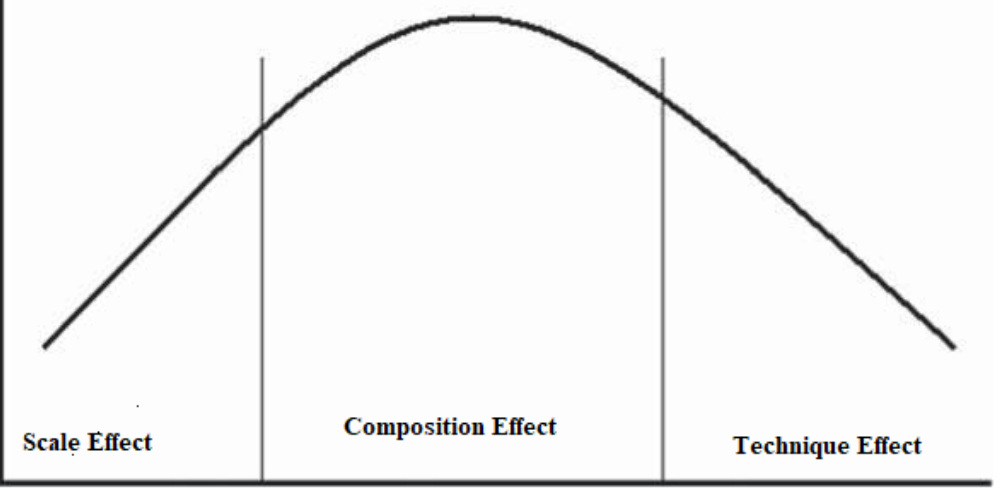

Economic Growth

114 Figure 1. Environmental Kurnets curve and frequencies of sustainable development effect by Shabbaz, \& Sinha, (2019).

From a different viewpoint, this whole scenario can be seen from the point of view of the

116 Group of Rome economists who managed to come up with their notion of The Limits to Growth in

117 1972. From their studies, economic development cannot proceed indefinitely due to an insufficient

118 supply of natural resource extraction (Meadows et al., 1972). In 1992, when they publish The First

119 Global Revolution, the Club of Rome claimed that man interference in social systems has contributed

120 to issues such as emissions levels, water shortages and climate change, which had been known to be

121 the key indicators of climate destruction (King \& Schneider, 1992). Despite being disputed by many

122 economists on the grounds of different points of view and relevant theoretical structure problems

123 (Turner, 2008), the advent of principles such as socioeconomic equality (Solow, 1974) and the ideal

124 ordinary reserve exploitation track (Stiglitz, 1974a, b) has shown that the problems posed by the Club

125 of Rome economists are noteworthy for sustained progress development. The expansion of this 
theory was embodied in the principle of an endogenous self-regulatory ordinary resource business system (Unruh \& Moomaw, 1998). In the initial stages of socio-economic development, additional emphasis is assumed to the main (agricultural) in addition to supplementary (industrial as well as production) areas and thus a high degree of extraction of natural resource extraction has been confronted. This misuse of natural resources leads to a greater loss of natural resources. As long as the supply of real resource extraction is unchanged at the start of industrial expansion and increased rates of global development result in increased demands for real resources, the cost of real resources is continuing to climb. This increase in the price of real resources discourages manufacturing homes from using more renewable resources because it raises the production costs and thus tends to move to less asset-overriding or commodity-effective technology (Duflou et al., 2012). This transition is taking effect at the latter periods of social and social development and is thus accountable for enhancing the efficiency of the atmosphere. We may also now see that the market apparatus is also liable for choosing the form of the EKC.

From the concept above, this study, therefore, looks into the N-shape EKC association regarding output and pollution by analyzing if EKC theory can be identified within the E7 states. Additionally, the U-shape EKC has been widely investigated therefore we consider to add to the existing literature by filling the unfilled gap in the literature. However, to our point of view, none of the existing researchers analyzed the $\mathrm{EKC} \mathrm{N}$-shaped association among $\mathrm{CO}_{2}$ pollutants and GDP growth by utilizing the PMG-ARDL technique, incorporating external control variables such as green power usage as well as non-renewable power usage. Therefore, the main purpose of this analysis is to analyze the $\mathrm{N}$-shaped EKC within the E7 ecosystem by using data from the WDI from the period of 1995 to 2018. Nevertheless, we examine if the environmental pollution of E7 societies impacts their commercial activity. There are many strategic explanations for classifying nations into separate categories. For instance, it is essential to research the E7 economies collectively (China, India, 
150 Indonesia, Brazil, Russia, Mexico and Turkey) because they are developing economies, most of which

151 are middle-income economies and subject to $73 \%$ of the poor in the world citizens around five billion

152 of the earth's seven billion population. Moreover, middle-income nations are the primary engines of 153 economic development (World Bank 2017a).

This is premised on the fact that ecological deterioration cannot be influence only by socioeconomic growth, we do add parameters to monitor the impact of clean power usage and nonrenewable power usage on ecological deterioration. We plan to address the relevant hypotheses: what

157 is the connection regarding ecological destruction and socio-economic growth in the E7 nations?

158 What can ecological pollution be clarified by the use of green energies and non-renewable resources?

159 We used the PMG-ARDL panel to answer our study hypothesis. Also, the Heterogeneous Causality 160 Investigation was used to describe the causal connection regarding the variables. Yearly statistics were 161 collected from the World Development Indicators (WDI) databank representing the E7 nations (made 162 up of Brazil, China, India, Indonesia, Russia, Mexico and Turkey) throughout the span 1995-2018.

164 shaped association regarding countries and ecological deterioration base on the E7 economy. 165 Established research focuses primarily on specific nations, OECD countries, or broader sampling 166 sizes of nations, but none has a focus on E7 states. This is a void in the current EKC documentation 167 which we plan to fill by using PMG-ARDL regressions to recognize EKC in the E7 nations. Lastly, 168 the literature on the N-shape EKC has not established ell which scholars are still investigation 169 therefore, this current study will add up to the existing literature. This paper is structured as follows: Section 2 provides a review of related literature. Section 3 171 focuses on data and methodological procedure employed. While Section 4 concentrates on the 
172 interpretation of empirical findings. Finally, section 5 concludes the study with policy prescriptions

173 accordingly.

\section{2. Literature review}

175

176

177

178

179

180

181

182

183

184

185

186

187

The EKC was originally introduced by Grossman \& Krueger (1991), to demonstrate the connection regarding sustainable development as well as ecological destruction has the nature of an inverted U. Consequently, several studies have made efforts to empirically assess the hypothesis ( Adedoyin, Abubakar, Victor, \& Asumadu, 2020; Adedoyin, Alola, \& Bekun, 2020; Adedoyin, Gumede, Bekun, Etokakpan, \& Balsalobre-lorente, 2020; Etokakpan, Adedoyin, Vedat, \& Bekun, 2020; Kirikkaleli, Adedoyin, \& Bekun, 2020; Udi, Bekun, \& Adedoyin, 2020, Gyamfi et al, 2020a, Sarpong et al. 2020, Gyamfi et al. 2020b). The N-shaped EKC shows that perhaps the initial EKC theory would not be preserved in the longer term. Alternatively, the rise in wages more than a specific amount of income could contribute to a favourable correlation regarding sustainable development and ecological destruction Torras \& Boyce (1998) indicate that perhaps the N-shaped dynamic takes place as the level impact overwhelms structure and technological consequences. This may be attributed to limited incentives to somehow develop the production of resources or to decreased gains on technical progress (Álvarez-Herranz \& Balsalobre Lorente 2015).

After Grossman \& Krueger (1991) first recorded an inverted U-shaped association regarding emission as well as revenue, detailed work has been performed into the EKC phenomenon (Ekins 1997; Acaravci et al. 2009). All of these analyses have studied the connection among sustainable development and ecological degradation under the EKC analytical framework, suggesting a connection among economic development and ecological sustainability, whereas ecological degradation is a growing aspect of the degree of socioeconomic development before a crucial threshold is achieved, after which better earnings levels contribute to an increase in ecological performance. 
The central point is that global development influences the world in 3 contexts: the impact of

197 size, the impact of structure and the technological influence (Grossman and Krueger 1991). The effect

198 of sustainable development on ecological destruction can thus also be split together into the same 3

199 sections (Grossman \& Krueger 1995).

200

201

202

203

204

205

206

207

208

209

210

211

212

213

214

215

216

217

218

(a) The scale impact ensures that although the socioeconomic system and infrastructure of a nation do not shift, an improvement in demand would contribute to a decline in ecological sustainability. It may therefore be claimed that the influence of sustainable development on the scale has a detrimental environmental influence.

(b) The compositional influence can have a beneficial influence on the ecosystem because, at the initial phases of socioeconomic activity, emissions rise as the socioeconomic system changes from farming to more asset-intensive large industrial enterprises, while at the subsequent phases, emissions declines as the framework changes to utilities and small processing companies. As a result of this shift in the manufacturing system, the compositional impact may reduce the negative impact of sustainable development on ecological emissions. The compositional influence happens as the manufacturing industry, with its heavy power usage and harmful pollution, is substituted by the retail industry, which reduces contaminating pollution and tends to change the bend (Hettige et al. 2000).

(c) The economic impact applies to efficiency improvements, also, the introduction of green technology, contributing to an improvement in ecological standards. The technological impact applies to new technology that allows the utilization of fewer supplies per amount of manufacture or the introduction of healthier technology to substitute outdated ones in the development of products. The creation of sustainable technology is promoted by investments in ecological RD\&D, which, in effect, involve adequate global expansion (Neumayer 1998). 

development in terms of size, structure and technological impact. At a reduced stage of production, ecological degradation relies on agricultural capital and a small supply of environmentally friendly

222 pollution. When global development accelerates by production, energy utilization and 223 industrialization, consumption levels tend to eclipse recycling levels, and pollution rises in both 224 volume and pollution. This is accompanied by the advent of knowledge and manufacturing sectors, 225 along with increasing climate issues, contributing to ecological protections, technical change and 226 increased expenditure in the ecosystem, which, in effect, promotes stability and a steady decline in 227 ecological degradation, in which technological advancement assumes a significant part (Andreoni \& 228 Levinson 2001).

The scale impact applies to the allowance for incremental developments to maximize the 230 benefit on the elimination of pollution (Torras and Boyce, 1998). The scale effect creates an increasing 231 pattern of the EKC as demand moves to urban demand, in so much as global growth leads to the 232 ability to expand in data-based industries and services, as well as in the advancement of manufacturing 233 technologies (composition impact) and the introduction of sustainable technologies (technical 234 impact). All of these latter impacts may surpass the level impact to create a decline in the EKC slope. 235 Additionally, Andreoni \& Levinson (1998) suggest that, as industrial development rises, the degree of 236 ecological toxicity is being reversed, primarily by technical influences. This insight connects the EKC 237 with advances in technology since the scientific influence is greater than the structure and scale impact.

239 Grossman \& Krueger (1995) in addition to Panayotou (1997) identified the N-shaped association 240 involving socioeconomic progress as well as sulfur dioxides (SO2). For in cooperation instances, there

241 were little results during the 2nd changing stage, because it remained towards the far edge of the 
242 information gathering, as well as indeed the N-shape was rejected. Moomaw \& Unruh (1997) consider

243 the N-shaped EKC while utilizing FEM as well as cross-section OLS. Nevertheless, the researchers

244 have employed a systemic change method that suggested that the move to reducing $\mathrm{CO}_{2}$ pollution

245 was the most probable outcome of the oil shock of 1973.

The effect of clean power on ecological destruction has been extensively researched in modern

247 decades. Various reports show that greenhouse gas (GHG) emissions will be decreased when coal and

248 oil are substituted by clean energies (Shafiei \& Salim 2014, 2016; AlMulali et al. 2016, Bekun and

249 Gyamfi, 2020, Ozcan and Ozturk, 2019). Clean power use would also have a detrimental effect on

250 pollution (Shaahbaz and Sinha, 2019). Currently, Shahbaz et al. (2017) have shown that power

251 conservation use is essential for long-term sustained economic growth in twenty-five advanced

252 economies over the duration 1970 to 2014. Furthermore, Lu (2017) reports that there is a long-term

253 correlation between green power use, pollutant and GDP, considering panel information for twenty-

254 four Asian states regarding the duration of 1990 to 2012. Paramati et al. (2017) Examination of the

255 following 11 states shows that clean power growth and different business operations are necessary for

256 stable business growth. In the 1980-2010 panel of 24 nations of sub-Saharan Africa, Ben Jebli et al.

257 (2015) examined the short-term and long-term link regarding $\mathrm{CO}_{2}$ emissions, GDP, clean energy use

258 and foreign trade, based on an Environmental Kuznets Curve (EKC) hypothesis. Short-run Granger

259 causality findings showed a bidirectional causality regarding pollution and economic development,

260 bidirectional causality from pollution to actual exports, unidirectional causality from real imports to

261 emission levels and unidirectional causation from trade to the use of renewables. Long-term forecasts

262 indicate that these nations do not accept the inverted EKC U-shaped hypothesis: exports have a

263 positive effect on $\mathrm{CO}_{2}$ emissions, whereas imports harm the environment. Nevertheless, Rauf et al

264 (2018) studied for the Belt and Road Initiative (BRI) economics on Environmental Curve Kuznets

265 theory that mega-projects in BRI will be an indicator of environmental damage. The on-site analysis 
includes new data from 1981 to 2016 with a specific emphasis on heterogeneity and cross-sectional

267 dependency. The measured results show that the average group estimator offers good evidence and

268 favours EKC in nearly every area. The long-term effect is calculated by pooled mean group estimates,

269 which display substantial effects in each region; also, in the long term, the EKC hypothesis has been

270 proven in particular for the economies created.

272 the need to explore the connection between output and $\mathrm{CO}_{2}$ comprehensively by accessing for the N-

273 Shape EKC. The variables covered in this current study is timely and worthwhile given the

274 inconclusive outcomes in the literature in the energy-environment debate. To our best of knowledge,

275 none of the previously mentioned studies used a battery of techniques such as PMG-ARDL and the

276 heterogeneous causality test to estimate N-Shape EKC in terms of both long-and short-run which

277 this study intends to fill this gap. Furthermore, studies such as Shahbaz et al. (2018) concentrated on

278 the N-shape for the Middle East and North Africa countries whiles Halliru et al. (2020) concentrate

279 on six West Africa countries. Therefore these current studies differ in countries selection by

280 investigation the N-Shape for the E7 economics.

\section{3. Data and Methods}

$282 \quad 3.1$ Data

This section of the study outlines the material, method and variables. Subsequently, model 284 construction based on economic intuitions and empirical backing and onward results interpretation 285 and discussion. The data for this study covers the period 1995 to 2018. Data was sourced from two 286 sources namely the World Bank and The U.S. Energy Information Administration. The data on $\mathrm{CO}_{2}$ 287 emissions and GDP (GDP growth annual \%) were collected from the World Bank, while renewable 288 energy and non-renewable energy data were obtained from the U.S. Energy Information and 289 Administration database. A more detailed description of the data is shown in table 1. 


\begin{tabular}{|c|c|c|}
\hline Variable & Description & Source \\
\hline $\mathrm{LNCO}_{2}$ & Carbon dioxide emissions, thousands of tonnes & The World Bank \\
\hline GDP & GDP growth (annual \%) & The World Bank \\
\hline LNNREC & $\begin{array}{l}\text { The sum of Gasoline production; Jet fuel } \\
\text { production; and Oil production (thousand barrels } \\
\text { per day) }\end{array}$ & $\begin{array}{l}\text { The U.S. Energy } \\
\text { Information } \\
\text { Administration }\end{array}$ \\
\hline LNREC & $\begin{array}{l}\text { Renewable power generation, billion kilowatt- } \\
\text { hours }\end{array}$ & $\begin{array}{l}\text { The U.S. Energy } \\
\text { Information } \\
\text { Administration }\end{array}$ \\
\hline
\end{tabular}

Source: Authors compilation

\subsection{Model and Methods}

300

301

$$
\text { LNC02 }_{2} \alpha_{0}+\beta_{1} G D P_{i t}+\beta_{2} \text { GDPsquare }_{i t}+\beta_{3} \text { GDPcubed }_{i t}+\beta_{4} \text { LNEC }_{i t}+\beta_{5} L N N E C_{i t}+\varepsilon_{i t}
$$
The variables in the model have undergone a logarithmic transformation to ensure they maintain a

This analysis aim is to look at the presence of $\mathrm{N}$-shaped $\mathrm{EKC}$ in the emerging 7 states. As mentioned in the literature review, few studies have been carried out for other groups of countries. Hence, this study is one of the first to consider this topic for the E7 countries. In other to estimate the impact of GDP, renewable energy and non-renewable energy intake on $\mathrm{CO}_{2}$ emissions and to analyse the development of the EKC in the $\mathrm{E} 7$ countries the following model equation is proposed:

$$
\mathrm{LNCO}_{2}=f(G D P, L N R E C, L N N R E C)
$$
constant variance across all the series. Where LNC02, LNEC, LNNEC are logarithmic transformations of all variables and $\varepsilon_{i t}, \alpha$ and $\beta$ 's represent the stochastic, intercept, and partial slope 

coefficients respectively. Hence, the GDP, GDP square and GDP cubed were not in their logarithmic

308 form because the GDP annual growth \% was employed which does not need to be logged.

309 We employ the Pooled Mean Group-Autoregressive Distributed Lag (PMGARDL) estimator to 310 analyses the variables of interest. This method will enable us to assess together the short and long run 311 approximations utilising the Pesaran et al. (1999) technique. The analysis will involve an 312 Autoregressive Distributed Lag (ARDL: p, q) structure that integrates lags of $\mathrm{CO}_{2}$ pollutants and other 313 control variables, shown by:

$$
L N C 02_{i t}=\beta_{i}+\sum_{j=0}^{p} \delta_{i j} L N C O 2 Z_{i t-j}+\sum_{j=1}^{q} \varphi \delta_{i, j} Z_{i t-j}+\varepsilon_{i t}
$$

316 where, $\mathrm{Z}_{\mathrm{it}}=\left(\mathrm{LNREC}_{\mathrm{it}}, \mathrm{LNNEC}_{\mathrm{it}}, \mathrm{GDP}_{\mathrm{it}}\right)$ which is a vector of descriptive variables utilised in this 317 analysis. $\beta_{\mathrm{i}}$ symbolizes the country-level fixed effects, $\delta_{\mathrm{ij}}$ symbolizes slope of the lagged emissions 318 variable and $\varphi_{i, j}$ symbolizes the slope of lagged explanatory variables.

319 The ARDL cointegration estimator is more useful than the traditional panel data models. It is capable 320 of accounting for endogeneity matters in econometric representations and at the similar period 321 accommodate together short-run and long-run strictures. The ARDL cointegration assessment also 322 allows the use of variables in a varied order of combination for instance $\mathrm{I}(0)$ or/and I(1), not I (2). 323 According to Pesaran et al. (1999), the Pool Mean Group (PMG) estimator is dependable, robust as 324 well as durable to lag orders and outliers.

\section{4. Results, Discussions and Implication of research findings}

\subsection{Pre-estimation Diagnostics}


329 The second table shows the summary statistics of the variables in the model. It appears that GDP has

330 the highest average value of 5.11 million dollars per annually, single maximum values of 14.23 million

331 dollars per annually, and minimum value of 4.69 million dollars per annually and is the most dispersed

332 variable in the model. The next is nonrenewable energy which has an average of 4.42 metric tons per

333 year, a minimum of 3.94 metric tons per year and a maximum of 4.53 metric tons per year. Renewable

334 energy fellow with an average of 3.05 metric tons per year, a minimum of 1.17 metric tons per year and a maximum of 3.99 metric tons per year. While emission is the least with an average of 1.15 metric tons per year, a minimum of -0.17 metric tons per year and a maximum of 2.55 metric tons per year.

337 The Jaque-Bera values show that the observations are typically dispersed. Table 3 presents the relationship matrix and it reveals that there is a negative linear connection regarding GDP, clean energy

339 in addition to the dependent variable $\mathrm{CO}_{2}$ emissions. On the other hand, there seems to be a positive

340 linear connection regarding non-renewable energy as well as $\mathrm{CO}_{2}$ emissions. Again, the output is found 341 to have a positive correlation with clean energy and non-renewable energy while clean energy has a 342 negative correlation with non-renewable energy.

Table 2. Summary Statistics

\begin{tabular}{|l|c|c|c|c|}
\hline & LNCO $_{2}$ & GDP & LNREC & LNNREC \\
\hline Mean & 1.161160 & 5.087110 & 2.912826 & 4.330405 \\
\hline Median & 1.151564 & 5.109085 & 3.046483 & 4.427331 \\
\hline Maximum & 2.548271 & 14.23139 & 3.997909 & 4.530320 \\
\hline Minimum & -0.172050 & 4.687110 & 1.171799 & 3.938051 \\
\hline Std. Dev. & 0.739137 & 4.089790 & 0.909775 & 0.187458 \\
\hline Skewness & 0.259702 & -1.100349 & -0.583705 & -0.557863 \\
\hline Kurtosis & 2.177571 & 5.205376 & 2.081083 & 1.766685 \\
\hline Jarque-Bera & 6.623185 & 67.94725 & 15.45078 & 19.36136 \\
\hline Probability & 0.036458 & 0.000000 & 0.000441 & 0.000062 \\
\hline Sum & 195.0748 & 787.4345 & 489.3548 & 727.5081 \\
\hline Sum Sq. Dev. & 91.23601 & 2793.306 & 138.2242 & 5.868471 \\
\hline Observations & 168 & 168 & 168 & 168 \\
\hline
\end{tabular}

Source: Authors computation with data from WDI 
Table 3. Correlation Matrix

347

\begin{tabular}{|l|l|l|l|l|}
\hline VARIABLES & LNCO $_{2}$ & GDP & LNREC & LNNREC \\
\hline $\mathrm{LNCO}_{2}$ & 1.0000 & & & \\
\hline p-value & - & & & \\
\hline GDP & -0.085029 & 1.0000 & & \\
\hline p-value & $(0.2731)$ & -- & & \\
\hline LNREC & $-0.948447 * * *$ & $0.145825^{*}$ & 1.0000 & \\
\hline p-value & $(0.0000)$ & $(0.0593)$ & --- & \\
\hline LNNREC & $0.783964^{* * *}$ & 0.070418 & $-0.845635^{* * *}$ & 1.0000 \\
\hline p-value & $(0.0000)$ & $(0.3644)$ & $(0.0000)$ & --- \\
\hline
\end{tabular}

348

Cointegration and Unit root tests

350 In other to test for cointegrating associations regarding the variables, the investigation adopts the

351 Johansen Fisher Panel cointegration test (Table 4) and the Kao's residual Cointegration tests (table 5).

352 As can be seen, the p-values obtained from the outcomes of both analysis endorse the existence of a cointegrating connection regarding the variables $\mathrm{CO}_{2}, \mathrm{GDP}$, clean energy and non-renewable energy

354 utilisation.

355 Table 6 shows the results for the unit root analysis. From the observation of the Augmented Dicker 356 Fuller (ADF) and Philips Perron (PP), unit root estimations agree that all variables are first difference 357 stationary. At levels with constant only one variable is stationary for both tests while at level with 358 constant and trend all variables are stationary in the ADF tests and only three for the PP test. However, 359 all variables are stationary at $\mathrm{I}(1)$ for all tests. Hence, we agree that all variables are first difference 360 stationary.

Table 4. Johansen Fisher Panel Cointegration Test

\begin{tabular}{|l|c|c|c|c|}
\hline $\begin{array}{l}\text { HYPOTHESIS } \\
\text { NO. OF CE(S) }\end{array}$ & $\begin{array}{l}\text { FISHER STAT } \\
\text { (from trace) }\end{array}$ & p-value & $\begin{array}{l}\text { FISHER STAT } \\
\text { (from max- } \\
\text { eight) }\end{array}$ & p-value \\
\hline $\mathrm{r} \leq 0$ & $52.54^{* * *}$ & $(0.0000)$ & $30.56^{* * *}$ & $(0.0064)$ \\
\hline
\end{tabular}




\begin{tabular}{|l|c|c|c|c|}
\hline $\mathrm{r} \leq 1$ & $31.14 * * *$ & $(0.0053)$ & $29.92^{* * *}$ & $(0.0078)$ \\
\hline $\mathrm{r} \leq 2$ & 12.74 & $(0.5474)$ & 14.01 & $(0.4488)$ \\
\hline $\mathrm{r} \leq 3$ & 8.985 & $(0.8320)$ & 8.985 & $(0.8320)$ \\
\hline
\end{tabular}

363 Table 5. Kao's (1999) residual cointegration test results

\begin{tabular}{|l|c|c|}
\hline & t-Statistic & p-value \\
\hline ADF & $-1.641311^{*}$ & $(0.0504)$ \\
\hline Residual variance & 0.003214 & \\
\hline HAC variance & 0.003059 & \\
\hline
\end{tabular}

Note: $* * * * *$ and $*$ are $1 \%, 5 \%$ and $10 \%$ significant level respectively

Table 6. Unit root Test

\begin{tabular}{|c|c|c|c|c|c|c|c|c|}
\hline \multicolumn{5}{|c|}{ ADF } & \multicolumn{4}{|c|}{ PP } \\
\hline & \multicolumn{2}{|c|}{ AT LEVEL } & \multicolumn{2}{|c|}{ AT 1ST LEVEL } & \multicolumn{2}{|c|}{ AT LEVEL } & \multicolumn{2}{|c|}{ AT 1 ${ }^{\text {ST }}$ LEVEL } \\
\hline VARIABLES & $\pi \tau$ & $\pi \vartheta$ & $\pi \tau$ & $\pi \vartheta$ & $\pi \tau$ & $\pi \vartheta$ & $\pi \tau$ & $\pi \vartheta$ \\
\hline $\mathrm{LNCO}_{2}$ & 0.8590 & $0.7462^{* *}$ & $0.0005^{* * *}$ & $0.0033^{* * *}$ & 0.8617 & 0.7058 & $0.0005^{* * *}$ & $0.0033^{* * *}$ \\
\hline GDP & $0.0023^{*}$ & $0.0076^{* *}$ & $0.0000^{* * *}$ & $0.0002^{* * *}$ & $0.0023^{* *}$ & $0.0005^{* *}$ & $0.0000^{* * *}$ & $0.0000^{* * *}$ \\
\hline LNREC & 0.9893 & $0.5866^{*}$ & $0.0669 * * *$ & $0.1242 * * *$ & 0.9960 & $0.7302 *$ & $0.0730^{* * *}$ & $0.1296^{* * *}$ \\
\hline LNNREC & 0.8675 & $0.4162 *$ & $0.0002^{* * *}$ & $0.0016^{* * *}$ & 0.8675 & 0.4098* & $0.0002 * * *$ & $0.0016^{* * *}$ \\
\hline
\end{tabular}

Note: $* * *, * *$ and $*$ are $1 \%, 5 \%$ and $10 \%$ significant level respectively Note: $* * *, * *$ and $*$ are $1 \%, 5 \%$ and $10 \%$ significant level respectively;

thus, $\pi \tau$ is with constant, $\pi \vartheta$ is with constant and trend

\subsection{Estimation Results}

Table 7 shows long-run PMG-ARDL results for two models. The long-run estimation of the

3717 states which are unlike the study of Shahbaz et al. (2018) that affirms the N-Shape EKC for the

372 Middle East and North Africa countries. Rather, the outcome approves the presence of an inverted

373 U-shaped EKC in the focus states as shown by a positive coefficient of GDP and the negative

374 coefficient of GDP squared at $1 \%$ levels of significance. This signifies that at an earlier stage of

375 economic expansion emissions increase but a later stage of economic expansion emissions begins to

376 fall after which there no further rise in emissions as is evidenced by the insignificant coefficient of

377 GDP cubed. This finding is similar to that of Luzzati \& Orsini (2009) and Acaravci et al. (2009). But

378 it is different from that of Álvarez-Herranz \& Balsalobre Lorente (2015). There is no significant

379 connection regarding clean energy utilisation and $\mathrm{CO}_{2}$ pollutants and it does not affirm the finding of 
Gyamfi et al, (2020) which states that clean energy is significant in the G7 economy. From a different

381 point of view, non-renewable energy has a positive influence on pollutant at a $1 \%$ level of significance.

382 Specifically, a percentage increase in non-renewable power utilisation will lead to a $4.301 \%$ rise in

383 pollutants which is a more than proportional change. This outcome implies that non-renewable energy

384 is a major driver of pollutants in the emerging 7 states. Studies by Attiaoui I. et al (2017) reached 385 similar conclusions.

Similarly, results from the second-long run model affirm the presence of an inverted U-shaped

387 EKC in the emerging 7 countries. The nature of the EKC is shown by the positive connection

388 regarding GDP and pollutants and the negative association regarding GDP squared and pollutants.

389 Going further, outcomes show that renewable energy leads to high pollutants in the focus countries 390 by an average of $0.4881 \%$. This result is not as expected given that renewable energy comprises of

391 non- $\mathrm{CO}_{2}$ emitting energy resources. Similarly, non-renewable energy harms pollutants at a $1 \%$ level of

392 significance. This outcome is as expected since non-renewable energy often comprises of $\mathrm{CO}_{2}$ emitting 393 energy resources which is a major source of energy among the E-7 countries.

394 Table 7. ARDL Long Run Estimation Results

\begin{tabular}{|l|l|l|}
\hline VARIABLES & ARDL(3, 1, 1, 1, 1, 1) & ARDL(2, 1, 1, 1, 1) \\
\hline GDP & $0.057257^{* * *}$ & $0.064897 * *$ \\
\hline p-value & $(0.0075)$ & $(0.0135)$ \\
\hline GDP & $-0.009240^{* * *}$ & $-0.006666^{* * *}$ \\
\hline p-value & $(0.0059)$ & $(0.0049)$ \\
\hline GDP & 0.000385 & - \\
\hline p-value & $(0.1878)$ & - \\
\hline LNREC & 0.224716 & $0.488172^{* *}$ \\
\hline p-value & $(0.2226)$ & $(0.0405)$ \\
\hline LNNREC & $4.301323^{* * *}$ & $4.621717 * * *$ \\
\hline p-value & $(0.0000)$ & $(0.0000)$ \\
\hline
\end{tabular}


Table 8 presents the short-run results for the estimated models. The negative and significant error correction terms signify that there is a significant long-run association concerning the variables in the model. Also, short-run results for the main model (column 2, Table 8) reveal that there is no significant relationship between the lagged values of $\mathrm{CO}_{2}\left(\mathrm{LNCO}_{2}(-1), \mathrm{LNCO}_{2}(-2)\right)$ and $\mathrm{CO}_{2}$ emissions in the current period. Similarly, economic expansion has no significant short-run effect on pollutants as shown by the insignificant coefficients of GDP, GDP-squared, and GDP-cubed. Likewise, clean energy utilisation and non-renewable energy utilisation have no significant impact on emissions in the 404 short run.

405

The outcome for the second short run estimation $\operatorname{ARDL}(2,1,1,1,1)$ is similar to that of ARDL $(3,1,1,1,1)$. The lagged value of $\mathrm{CO}_{2}\left(\mathrm{LNCO}_{2}(-1)\right)$ does not have a significant influence on 407 pollutants in the short run. Also, the insignificant coefficients of GDP and GDP-squared show that 408 there is no significant short-run association concerning economic expansion and pollutants in the E-

4097 countries. In the same vein, the results for clean energy utilisation and non-renewable energy 410 utilisation reveal that both have no significant effects on emissions in the $\mathrm{E} 7$ countries.

Table 8. Short-run ARDL Test

\begin{tabular}{|c|c|c|c|}
\hline \multicolumn{4}{|c|}{ SHORT-RUN EQUATION } \\
\hline \multicolumn{2}{|c|}{$\operatorname{ARDL}(3,1,1,1,1,1)$} & \multicolumn{2}{|l|}{$\operatorname{ARDL}(2,1,1,1,1)$} \\
\hline VARIABLES & COEFFICIENT & VARIABLES & COEFFICIENT \\
\hline COINTEQ01 & $-0.175277 *$ & COINTEQ01 & $-0.123474 * *$ \\
\hline $\mathrm{D}\left(\mathrm{LNCO}_{2}(-1)\right)$ & 0.158827 & $\mathrm{D}(\mathrm{LNCO} 2(-1))$ & 0.147377 \\
\hline $\mathrm{D}\left(\mathrm{LNCO}_{2}(-2)\right)$ & -0.038580 & $\mathrm{D}(\mathrm{GDP} 1)$ & 0.019936 \\
\hline $\mathrm{D}(\mathrm{GDP})$ & -0.026704 & $\mathrm{D}(\mathrm{GDP} 2)$ & -0.000989 \\
\hline $\mathrm{D}\left(\mathrm{GDP}^{2}\right)$ & 0.006916 & $\mathrm{D}(\mathrm{LNREC})$ & -0.080294 \\
\hline $\mathrm{D}\left(\mathrm{GDP}^{3}\right)$ & -0.000393 & D(LNNREC) & 0.063209 \\
\hline $\mathrm{D}(\mathrm{LNREC})$ & 0.293390 & $\mathbf{C}$ & $-2.570884^{* *}$ \\
\hline D(LNNREC) & 0.524887 & & \\
\hline $\mathrm{C}$ & $-3.266532^{*}$ & & \\
\hline
\end{tabular}

$413 \quad 4.3$ Heterogeneous Causality Test 
Apart from assessing the long and short-run interconnectedness among variables, it is

415 important to evaluate the legitimacy of the direction of causality among the selected variables. This

416 will help inform policy direction. Table 9 displays the outcomes for the heterogeneous causality test.

417 The outcomes display that there is bi-directional causality concerning GDP and GDP-squared. This

418 signifies that there is a feedback mechanism between GDP and GDP squared further implying that

419 income at the initial stage of development (GDP) can predict income at a later phase of development

420 (GDP-squared) and vice versa. From the other point of view, there is unidirectional causality from

$421 \mathrm{CO}_{2}$ pollutants to GDP-cubed, non-renewable energy and $\mathrm{CO}_{2}$ pollutants, renewable energy and $\mathrm{CO}_{2}$

422 pollutants. This illustrates that $\mathrm{CO}_{2}$ emissions have a direct effect on income at a third phase of

423 development (GDP-cubed) in the E7 countries and that non-renewable energy use has a direct effect

424 on pollutants which is a positive impact (according to the estimation results in table 7). Similarly,

425 cleaner energy also has a direct effect on pollutants which appears to be a negative impact (see results

426 in table 7), implying that increased use of cleaner energy will cause a fall in emissions. Based on the

427 results of this paper, it is prudent for the E7 countries to actively invest in research and development

428 and identify a more refined technical means to increase the consumption clean energy to shift away

429 from non-renewable which has a direct impact on the economy. This will help play a key role in 430 combating carbon dioxide for a healthy atmosphere for its population.

431 Table 9. Result of Causality test

\begin{tabular}{|c|c|c|}
\hline Null Hypothesis: & Zbar. Stat & p-value \\
\hline $\mathrm{GDP} \neq \mathrm{LNCO}_{2}$ & -1.09002 & $(0.2757)$ \\
\hline $\mathrm{LNCO}_{2} \neq \mathrm{GDP}$ & 1.49685 & $(0.1344)$ \\
\hline $\mathrm{GDP}^{2} \neq \mathrm{LNCO}_{2}$ & -0.85429 & $(0.3929)$ \\
\hline $\mathrm{LNCO}_{2} \neq \mathrm{GDP}^{2}$ & 0.63815 & $(0.5234)$ \\
\hline $\mathrm{GDP}^{3} \neq \mathrm{LNCO}_{2}$ & -1.12777 & $(0.2594)$ \\
\hline $\mathrm{LNCO}_{2} \neq \mathrm{GDP}^{3}$ & $1.76631 *$ & $(0.0773)$ \\
\hline $\mathrm{LNNREC} \neq \mathrm{LNCO}_{2}$ & $4.75937 * * *$ & $(2 . \mathrm{E}-06)$ \\
\hline $\mathrm{LNCO}_{2} \neq \mathrm{LNNREC}$ & -0.45317 & $(0.6504)$ \\
\hline $\mathrm{LNREC} \neq \mathrm{LNCO}_{2}$ & $2.59323^{* * *}$ & $(0.0095)$ \\
\hline
\end{tabular}




\begin{tabular}{|c|c|c|}
\hline $\mathrm{LNCO}_{2} \neq \mathrm{LNREC}$ & -1.02562 & $(0.3051)$ \\
\hline $\mathrm{GDP}^{2} \neq \mathrm{GDP}$ & $1.99719 * *$ & $(0.0458)$ \\
\hline $\mathrm{GDP} \neq \mathrm{GDP}^{2}$ & $2.01135^{* *}$ & $(0.0443)$ \\
\hline $\mathrm{GDP}^{3} \neq \mathrm{GDP}$ & 0.34293 & $(0.7316)$ \\
\hline $\mathrm{GDP} \neq \mathrm{GDP}^{3}$ & 0.79047 & $(0.4293)$ \\
\hline LNNREC $\neq$ GDP & -0.13602 & $(0.8918)$ \\
\hline GDP $\neq$ LNNREC & -1.43364 & $(0.1517)$ \\
\hline LNREC $\neq$ GDP & 0.56759 & $(0.5703)$ \\
\hline GDP $\neq$ LNREC & -0.75735 & $(0.4488)$ \\
\hline $\mathrm{GDP}^{3} \neq \mathrm{GDP}^{2}$ & $2.54868^{* *}$ & $(0.0108)$ \\
\hline $\mathrm{GDP}^{2} \neq \mathrm{GDP}^{3}$ & $4.07425^{* * *}$ & $(5 . \mathrm{E}-05)$ \\
\hline LNNREC $\neq$ GDP ${ }^{2}$ & 0.47231 & $(0.6367)$ \\
\hline $\mathrm{GDP}^{2} \neq \mathrm{LNNREC}$ & -1.52168 & $(0.1281)$ \\
\hline LNREC $\neq$ GDP $^{2}$ & $1.84577 *$ & $(0.0649)$ \\
\hline $\mathrm{GDP}^{2} \neq \mathrm{LNREC}$ & -0.32369 & $(0.7462)$ \\
\hline LNNREC $\neq \mathrm{GDP}^{3}$ & 0.63014 & $(0.5286)$ \\
\hline $\mathrm{GDP}^{3} \neq \mathrm{LNNREC}$ & -1.45476 & $(0.1457)$ \\
\hline $\mathrm{LNREC} \neq \mathrm{GDP}^{3}$ & $2.71433^{* * *}$ & $(0.0066)$ \\
\hline $\mathrm{GDP}^{3} \neq \mathrm{LNREC}$ & -0.73576 & $(0.4619)$ \\
\hline LNREC $\neq$ LNNREC & 1.34950 & $(0.1772)$ \\
\hline LNNREC $\neq$ LNREC & $8.85108^{* * *}$ & $(0.0000)$ \\
\hline
\end{tabular}

Note: $* *, * *$ and $*$ are $1 \%, 5 \%$ and $10 \%$ significant level respectively while $\neq$ represents does not "Granger cause"

\section{Conclusion and Policy Implications}

The connection concerning economic activity and the environment has become an important topic of discussion, given the current wave of climate and environmental crisis traced to rising

437 environmental pollution from economic activities. It is even more important to investigate this 438 relationship in the Emerging-7 countries that are responsible for a large amount of global economic 439 activity. This analysis varies from the previous examination in the literature as it examines the N440 shaped EKC for the E-7 countries using data spanning the period 1995 to 2018. To analyze this 441 relationship the study employs the use of PMG-ARDL estimator and heterogeneous causality tests to

442 establish the long run and short-run and direction of causality respectively regarding the variables of 443 interest. 
445 shaped EKC in the emerging 7 states but rather confirms the presence of an inverted U-shaped EKC

446 in the examine nations. While non-renewable energy has a positive and significant relationship with

$447 \mathrm{CO}_{2}$ pollutants. Short-run outcomes display that there is no significant connection concerning 448 economic expansion, cleaner energy, non-renewable energy and $\mathrm{CO}_{2}$ emissions. Causality tests showed 449 a bi-directional causality regarding GDP and GDP-squared, and a uni-directional causality from $\mathrm{CO}_{2}$ 450 emissions to GDP-cubed, non-renewable energy and $\mathrm{CO}_{2}$ emissions, clean energy and $\mathrm{CO}_{2}$ emissions. and foremost, this study recognizes the significance of energy in powering sustainable development

453 in the E7 countries. Despite the importance of achieving high target sustainable development and the 454 improved standards of living that follow, the harm imposed on the environment as a result of energy455 related emissions cannot be ignored. It then becomes necessary to look for sustainable means to 456 achieve economic development goals and improvement in the quality of the environs simultaneously.

457 This can be attained through the increased use of clean energy sources to power economic activities 458 as opposed to carbon-emitting energy resources. It, therefore, becomes necessary that more 459 investments be channelled towards harnessing renewable energy sources sufficient to drive economic 460 needs and other forms of energy demand. With renewable energy, the E7 countries will pursue 461 ambitious economic growth without threatening the quality of the environment. In the same vein, the 462 government can encourage the use of renewable energy by providing economic incentives such as tax 463 breaks for firms that agree to adopt clean energy for production activities. With such motivation, there 464 will be increased use of renewable energy in the E7 countries and emissions will be on a downward 465 slope. In the same vein, the government should discourage the use of fossil fuels by imposing a carbon 466 tax on high carbon-emitting activities. Such a measure could go a long way to discourage the use of 467 fossil fuels thus, arresting emissions and its harmful impact on the environment. With the 
implementation of these measures will aid the E7 countries in contributing to the attainment of the Paris accord-global agreement to cut emissions by 1.5 degree Celsius.

This study employed $\mathrm{CO}_{2}$ emissions as a proxy for the quality of the environment. future studies can consider using Ecological Footprints (EFP) as a proxy for environmental quality considering its ability to represent natural resources. Individual studies could also be carried out on a related topic to have a more appropriate document for environmental policy for specific countries.

\section{Reference}

Acaravci, A. and Ozturk, I. (2010), "On the relationship between energy consumption, CO2 emissions and economic growth in Europe”, Energy, Vol. 35 No. 12, pp. 5412-5420.

Acaravci, S. K., Ozturk, I., \& Acaravci, A. (2009). Financial development and economic growth: Literature survey and empirical evidence from Sub-Saharan African countries. South African Journal of Economic and Management Sciences, 12(1), 11-27.

Adedoyin, F. F., Alola, A. A., \& Bekun, F. V. (2020). An assessment of environmental sustainability corridor: The role of economic expansion and research and development in EU countries. $\begin{array}{lllll}\text { Science of the Total } & 136726 .\end{array}$ https://doi.org/10.1016/j.scitotenv.2020.136726

Adedoyin, F. F., Gumede, I. M., Bekun, V. F., Etokakpan, U. M., \& Balsalobre-lorente, D. (2020). Modelling coal rent, economic growth and CO2 emissions: Does regulatory quality matter in BRICS economies? Science of the Total Environment, 710, 136284. https://doi.org/10.1016/j.scitotenv.2019.136284

Adedoyin, F., Abubakar, I., Victor, F., \& Asumadu, S. (2020). Generation of energy and environmental-economic growth consequences: Is there any difference across transition economies? Energy Reports, 6, 1418-1427. https://doi.org/10.1016/j.egyr.2020.05.026

Agboola, M. O., \& Bekun, F. V. (2019). Does agricultural value added induce environmental degradation? Empirical evidence from an agrarian country. Environmental Science and Pollution Research, 26(27), 27660-27676.

Al-Mulali U, Ozturk I, Solarin SA (2016) Investigating the environmental Kuznets curve hypothesis in seven regions: the role of renewable energy. Ecol Indic 67:267282

Álvarez A, Balsalobre D, Cantos JM (2015) Public budget for energy RD\&D and the effects on energy intensity and pollution levels. Environ Sci Pollut Res 22(7):4881-4892

Álvarez-Herranz A, Balsalobre Lorente D (2015) Energy regulation in the EKC model with a dampening effect. Int J Environ Anal Chem 2(3): 1-10 
Alvarez-López, C., Rojas, O. J., Rojano, B., \& Ganán, P. (2015). Development of self-bonded fiberboards from fiber of leaf plantain: Effect of water and organic extractives removal. BioResources, 10(1), 672-683.

Andreoni, J., \& Levinson, A. (1998). Simple Anal Environmental Kuznets Curve.

Andreoni, J., \& Levinson, A. (2001). The simple analytics of the environmental Kuznets curve. Journal of public economics, 80(2), 269-286.

Attiaoui I, Toumi H, Ammouri B, Gargouri I (2017) Causality links among renewable energy consumption, $\mathrm{CO} 2$ emissions, and economic growth in Africa: evidence from a panel ARDLPMG approach. Environ Sci Pollut Res 24(14):13036-13048

Bekun, F. V., \& Gyamfi, B. A. (2020). Rethinking the nexus between pollutant emission, financial development, renewable energy consumption and economic growth in G7 countries. SOCLAL, HUMAN AND ADMINISTRATIVE SCIENCES-II, 73.

Ben Jebli, M., Ben Youssef, S., \& Ozturk, I. (2015). The role of renewable energy consumption and trade: Environmental kuznets curve analysis for sub-saharan Africa countries. African Development Review, 27(3), 288-300.

Duflou, J.R., Sutherland, J.W., Dornfeld, D., Herrmann, C., Jeswiet, J., Kara, S., Hauschild, M. and Kellens, K. (2012), "Towards energy and resource efficient manufacturing: a processes and systems approach”, CIRP Annals - Manufacturing Technology, Vol. 61 No. 2, pp. 587-609

Ekins, P. (1997). The Kuznets curve for the environment and economic growth: examining the evidence. Environment and planning a, 29(5), 805-830.

Etokakpan, M. U., Adedoyin, F. F., Vedat, Y., \& Bekun, F. V. (2020). Does globalization in Turkey induce increased energy consumption: insights into its environmental pros and cons. Environmental Science and Pollution Research.

Grossman GM, Krueger AB (1991) Environmental impacts of a North American Free Trade Agreement. Working Paper No. 3914

Grossman GM, Krueger AB (1995) Economic growth and the environment. Q J Econ 110(2):353377

Grossman, G.M. (1995), "Pollution and growth: what do we know?”, in Goldin, I. and Winters, L.A. (Eds), The Economics of Sustainable Development, Cambridge University Press, Cambridge, MA, pp. 19-45

Gyamfi, B. A., Bein, M. A., \& Bekun, F. V. (2020). Investigating the nexus between hydroelectricity energy, renewable energy, non-renewable energy consumption on output: evidence from E7 countries. Environmental Science and Pollution Research, 27(20), 25327-25339.

Gyamfi, B. A., Bein, M. A., Ozturk, I., \& Bekun, F. V. (2020). The moderating role of employment in an environmental Kuznets curve framework revisited in G7 countries. Indonesian Journal of Sustainability Accounting and Management, 4(2).

Gyamfi, B. A., Sarpong, S. Y., \& Bein, M. A. (2020). The contribution of the anthropogenic impact of biomass utilization on ecological degradation: revisiting the G7 economies. Environmental Science and Pollution Research, 1-14. 
Halliru, A. M., Loganathan, N., \& Golam Hassan, A. A. (2020). Does FDI and economic growth harm environment? Evidence from selected West African countries. Transnational Corporations Review, 1-15.

Hettige, H., Mani, M., \& Wheeler, D. (2000). Industrial pollution in economic development: the environmental Kuznets curve revisited. Journal of development economics, 62(2), 445-476.

Hussen A (2005) Principles of environmental economics. Routledge, New York

King, A. and Schneider, B. (1992), The First Global Revolution, Orient Longman, Council of the Club of Rome, Washington, DC.

Kirikkaleli, D., Adedoyin, F. F., \& Bekun, F. V. (2020). Nuclear energy consumption and economic growth in the UK: Evidence from wavelet coherence approach. Journal of Public Affairs, (February), 1-11. https://doi.org/10.1002/pa.2130

López-Menéndez AJ, Moreno B, Pérez R (2014) Environmental costs and renewable energy: revisiting the environmental Kuznets curve. J Environ Manag 145:368-373

Lu WC (2017) Renewable energy, carbon emissions, and economic growth in 24 Asian countries: evidence from panel cointegration analysis. Environ Sci Pollut Res 24:26006-26615

Meadows, D.H., Meadows, D., Randers, J. and Behrens, W.W. III (1972), The Limits to Growth: A Report for the Club of Rome's Project on the Predicament of Mankind, Universe, New York, NY.

Moomaw WR, Unruh GC (1997) Are environmental Kuznets curves misleading us? The case of CO2 emissions. Environ Dev Econ 2: 451-463

Neumayer, E. (1998). Preserving natural capital in a world of uncertainty and scarce financial resources. The International Journal of Sustainable Development \& World Ecology, 5(1), 27-42.

Ozcan, B., \& Ozturk, I. (Eds.). (2019). Environmental Kuznets Curve (EKC): A Manual. Academic Press.

Panayotou T (1997) Demystifying the environmental Kuznets curve: turning a black box into a policy tool. Environ Dev Econ 2:465-464

Panayotou, T. (1993), "Empirical tests and policy analysis of environmental degradation at different stages of economic development”, Working Paper No. 292778, International Labour Organization, Geneva.

Paramati SR, Sinha A, Dogan E (2017) The significance of renewable energy use for economic output and environmental protection: evidence from the Next 11 developing economies. Environ Sci Pollut Res24:13546-13560

Rauf, A., Liu, X., Amin, W., Ozturk, I., Rehman, O. U., \& Hafeez, M. (2018). Testing EKC hypothesis with energy and sustainable development challenges: a fresh evidence from belt and road initiative economies. Environmental Science and Pollution Research, 25(32), 32066-32080.

Sarpong, S. Y., Bein, M. A., Gyamfi, B. A., \& Sarkodie, S. A. (2020). The impact of tourism arrivals, tourism receipts and renewable energy consumption on quality of life: A panel study of Southern African region. Heliyon, 6(11), e05351. 
608

609

610

611

Shafiei S, Salim RA (2014) Non-renewable and renewable energy consumption and CO2 emissions in OECD countries: a comparative analysis. Energ Policy 66:547-556

Shahbaz M, Shahzad SJH, Mahalik MK, Sadorsky P (2017) How strong is the causal relationship between globalization and energy consumption in developed economies? A country-specific time-series and panel analysis. Appl Econ. https://doi.org/10.1080/00036846.2017.1366640

Shahbaz, M., \& Sinha, A. (2019). Environmental Kuznets curve for CO2 emissions: a literature survey. Journal of Economic Studies.

Shahbaz, M., Balsalobre-Lorente, D., \& Sinha, A. (2019). Foreign direct Investment-CO2 emissions nexus in Middle East and North African countries: Importance of biomass energy consumption. Journal of cleaner production, 217, 603-614.

Solow, R.M. (1974), "Intergenerational equity and exhaustible resources", Review of Economic Studies, Vol. 41 No. 5, pp. 29-46.

Steffen W, Grinewald J, Crutzen P, Mc Neill J (2011) The Anthropocene: conceptual and historical perspectives. Philos Trans R Soc 369:842- 867

Stern DI (2004) The rise and fall of the environmental Kuznets curve. World Dev 32(8):1419-1439

Stiglitz, J. (1974a), "Growth with exhaustible natural resources: efficient and optimal growth paths", Review of Economic Studies, Vol. 41 No. 5, pp. 123-137.

Stiglitz, J. (1974b), "Growth with exhaustible natural resources: the competitive economy", Review of Economic Studies, Vol. 41 No. 5, pp. 139-152.

Torras M, Boyce JK (1998) Income, inequality, and pollution: a reassessment of the environmental Kuznets curve. Ecol Econ 25(2):147-160

Udi, J., Bekun, F. V., \& Adedoyin, F. F. (2020). Modeling the nexus between coal consumption, FDI inflow and economic expansion: does industrialization matter in South Africa? Environmental Science and Pollution Research. https://doi.org/10.1007/s11356-020-07691-x

United Nations (2017) The Paris Agreement. Retrieved from United Nations Framework Convention on Climate Change: http://unfccc. int/paris_agreement/items/9485.php (2020, Feb 15)

Unruh, G.C. and Moomaw, W.R. (1998), “An alternative analysis of apparent EKC-type transitions”, Ecological Economics, Vol. 25 No. 2, pp. 221-229.

World Bank (2017a) Middle income countries. Retrieved from World Bank: http://www.worldbank.org/en/country/mic/overview (2020, February 14) 


\section{Declarations}

\section{Availability of data and materials}

619 The data for this present study are sourced from the World Development Indicators 620 (https://data.worldbank.org/). The current data specific data can be made available upon request

621 but all available and downloadable at the earlier mentioned database and weblink

\section{Competing interests}

623 I wish to disclose here that there are no potential conflicts of interest at any level of this study.

\section{$624 \quad$ Funding}

625 I hereby declare that there is no form of funding received for this study.

\section{Authors' contributions}

627 The first authors (Dr Bright Akwasi Gyamfi) was responsible for the conceptual construction of 628 the study's idea. The second author (Dr Festus Fatai ADEDOYIN) handled the literature section 629 while third authors (Dr Festus Victor Bekun) managed the data gathering, preliminary analysis 630 and Prof. Dr Murad A. Bein was responsible for proofreading and manuscript editing.

\section{Acknowledgements}

632 Author gratitude is extended to the prospective editor(s) and reviewers that will/have spared time 633 to guide toward a successful publication.

634

Ethical Approval: Authors mentioned in the manuscript have agreed for authorship read and approved the manuscript, and given consent for submission and subsequent publication of the

638 Consent to Participate: Note Applicable

639 Consent to Publish: Applicable

640 The Authors of this article also assures that they follow the springer publishing procedures and

641 agree to publish it as any form of access article confirming to subscribe to access standards and 642 licensing. 
643 Many thanks in advance look forward to your favourable response

644 Yours truly,

645 Authors

646

647

648

649

650 